\title{
4 Managing Industrialisation in a Globalising Economy: Lessons from the Soeharto Era
}

\author{
HAL HILL AND DIONISIUS NARJOKO
}

One of the first decisions of the Soeharto administration was to re-engage with the global economy through a series of sweeping policy liberalisations. As a result, since the late 1960s Indonesia has been a largely open economy, and it has industrialised rapidly during most of this period. These two observations openness and rapid industrialisation - immediately raise a number of interesting and important analytical questions, for the country itself, for any evaluation of the Soeharto regime, and for development issues more generally.

For example, are these events connected and, if so, which way does the causality flow? More generally, how has increased integration into the global economy affected Indonesian industrialisation and economic development? It is a wellestablished proposition that more open economies generally grow more rapidly. But, equally, they are more vulnerable to sudden changes in the global economy, including especially external shocks. Moreover, answers to these questions shed light on the central question of this volume, concerning Soeharto's record and his legacy.

The 'general case' is of course an average of a highly diverse set of individual country observations. To gain deeper insights into these global-national interactions, detailed country case studies are an important supplement. Indonesia provides much illuminating material on these issues. ${ }^{1}$ Therefore, the purpose of this chapter is to examine the record of Indonesian industrialisation since the 1960s as the country became increasing integrated within the global economy. Two particular episodes are highlighted. First, we examine the three decades of rapid industrial growth and structural change during the Soeharto period, characterised by the adoption of broadly 'orthodox' economic policies and in the context of a largely benign and supportive international economic

1 We draw in particular on Hill, 1997 for an analysis of the Soeharto era industrialisation, and Narjoko, 2006 for a detailed, firm-level examination of the crisis impacts. See also Bird and Hill, 2006. 
environment. We then focus on the second episode, the impact of the deep economic crisis of 1997-98, and its immediate aftermath of painful restructuring and slower economic growth. We conclude by drawing some general lessons for Indonesia, and other developing economies, concerning the management of industrialisation strategies in an open economy.

At the outset, it needs to be emphasised that Soeharto presided over a remarkable industrial transformation of the country. For much of his period of rule, and certainly after the fading of the oil boom, industry was the leading sector of the economy. Its share of GDP and employment trebled and doubled respectively during this period. Real output rose approximately 18-fold. For the first time in its history, a sizeable factory sector emerged, and Indonesia became a significant industrial exporter. As we shall see below, for a complex set of economic and political reasons, post-Soeharto regimes have had difficulty matching these accomplishments.

\section{The New Order period: rapid industrialisation, 1967-97}

We highlight here four key features of industrialisation in the Soeharto era: growth, rapid structural change, the 1980s reforms and the shift to export orientation, and ownership patterns.

In the mid-1960s, Indonesia had barely commenced the process of modern industrialisation. It lagged well behind its Asian neighbours, experiencing neither the state-orchestrated heavy industrialisation of China and India, nor the export-oriented growth then getting under way in the Asian NIEs. Its modern industrial sector, such as it was, was dominated by a few large state-owned enterprises, which in most cases had been established by Dutch commercial interests before the Pacific War, and subsequently taken over by the state as part of the 1957-58 nationalisations.

First, Indonesia experienced very rapid industrialisation and structural change through to 1997, a sudden and sharp contraction in 1998, and slower growth thereafter (Table 4.1). Annual industrial growth was at least 9 per cent in all but two of the 27 years, 1970-96. Initially, catch-up and import substitution were the principal drivers. There was a decade of oil-driven growth, and the beginnings of a brief and costly heavy industry strategy. From the mid-1980s, labourintensive exports became a significant engine of growth. This growth came to an abrupt halt with the crisis of 1997-98. The contraction in the manufacturing sector was about the same as for the economy as a whole. Thereafter, positive growth has been recorded from 1999, but at lower rates than pre-crisis. 
Table 4.1: Economic Growth by Sector, 1970-2006

\begin{tabular}{lrrrr}
\hline Tradable & $1970-84$ & $1985-97$ & $1997-98$ & $1999-06$ \\
Agriculture & 5.1 & 5.4 & -1.7 & 3.5 \\
Mining and Quarrying & 3.7 & 2.9 & -0.2 & 2.9 \\
Manufacturing & 4.9 & 2.7 & -0.3 & 0.6 \\
Non-Tradable & 11.4 & 10.3 & -3.1 & 4.9 \\
$\quad$ Construction & 9.5 & 7.4 & -6.6 & 5.4 \\
Financial & 13.0 & 9.7 & -14.5 & 5.5 \\
$\quad$ Transport and Communication & 11.1 & 8.1 & -10.3 & 4.7 \\
$\quad$ Electricity, Gas and Water Supply & 11.1 & 7.5 & -4.1 & 9.6 \\
$\quad$ Trade, Hotel and Restaurant & 12.8 & 13.7 & 7.7 & 6.9 \\
$\quad$ Services & 8.0 & 7.5 & -6.2 & 4.9 \\
GDP & 8.0 & 4.6 & -0.1 & 4.0 \\
\hline
\end{tabular}

Second, accompanying this growth has been rapid structural change, as the industrial sector evolved from the production of simple consumer goods and basic resource processing to a wide range of manufactures of increasing technological sophistication. As noted, the process of modern industrialisation did not commence in Indonesia until the late 1960s. From 1965 to 1997, the share of the industrial sector in GDP more than trebled (Table 4.2). Within it, non-oil manufacturing grew very rapidly, its share of GDP more than doubling from 1980 to 1997. Since the crisis, the share of industry has remained broadly stable, with a slight dip in 1998-99 when resources returned to agriculture as a crisis-survival strategy.

Table 4.2: Share of GDP by Major Economic Sectors 1970-2006 (\%)

\begin{tabular}{lrrrr}
\hline Tradable & 1970 & 1985 & 1999 & 2006 \\
Agriculture & 72.3 & 56.7 & 53.0 & 51.1 \\
Mining and Quarrying & 55.3 & 22.7 & 17.1 & 14.1 \\
Manufacturing & 6.6 & 18.2 & 9.7 & 9.1 \\
Non-Tradable & 10.4 & 15.8 & 26.1 & 27.8 \\
$\quad$ Construction & 27.7 & 43.3 & 47.0 & 48.9 \\
$\quad$ Financial & 3.1 & 5.3 & 5.8 & 6.1 \\
$\quad$ Transport and Communication & 0.0 & 6.4 & 6.9 & 9.2 \\
$\quad$ Electricity, Gas and Water Supply & 3.6 & 5.3 & 7.1 & 6.7 \\
$\quad$ Trade, Hotel and Restaurant & 0.6 & 0.4 & 1.6 & 0.7 \\
$\quad$ Services & 20.5 & 14.6 & 15.8 & 16.9 \\
GDP & 0.0 & 11.3 & 9.8 & 9.2 \\
\hline
\end{tabular}


Within manufacturing, structural change has been equally rapid. Since 1975, when the industrial structure began to be measured on a regular and reasonably accurate basis, there has been a shift towards a more diversified industrial structure. The major labour-intensive and footloose industries grew rapidly during the export phase. Wood products expanded fast in response to the prohibition on the export of unprocessed timber, before encountering environmental constraints in the 1990s. Heavy industry grew quickly through to the mid-1980s in response to protection and major state investments. Within machinery and equipment, the auto industry grew rapidly under the impetus of prohibitive protection for most of the Soeharto period, but collapsed in 1998-99. Electronics has become increasingly important and export-oriented, but never as prominent as in neighbouring East Asian economies.

Third, Indonesia became a significant industrial exporter from the mid-1980s. In retrospect, the 1980s was a crucial period in Indonesian economic history. At the beginning of the decade, as oil prices first tapered off, and then fell sharply, the country was highly exposed to the international oil market. Oil, gas and related minerals provided about two-thirds of government revenue and almost three-quarters of merchandise exports. Indonesia could well have followed other major developing OPEC members - notably Mexico and Nigeria-into a debt crisis. ${ }^{2}$ Instead, the decline in oil prices triggered a major reassessment of trade and industry policy. The political economy pendulum swung in favour of the technocrats and their supporters who advocated a more liberal economic agenda, including reduced protection, a more open posture towards foreign investment, and simplified export procedures (Basri and Hill 2004).

Initially, manufactured exports were concentrated in resource-based activities, especially plywood, reflecting the country's natural resource endowments and the prohibition of unprocessed commodities (Table 4.3). Its industrial export base began to widen significantly as the reforms took hold, with textiles, garments, footwear, electronics, furniture, sporting goods and toys also registering rapid growth. The share of labour-intensive products in total manufactured exports increased in the wake of the 1980s reforms, from about 45 per cent in the mid1980s to 61 per cent by 1996. Export growth then tapered off in the post-reform period, mainly due to slower demand in Indonesia's major export destinations. Increased competition in export markets, a slackening in the reform momentum, slower productivity growth and the real rupiah appreciation around the mid1990s were also contributing factors.

2 See Gelb and Associates, 1988 for a comparative assessment of the management of the 1970s oil boom in selected developing countries. Indonesia emerges as the country which most effectively recycled its windfall oil boom revenues, and which adjusted most quickly to the downturn in prices. 
4 Managing Industrialisation in a Globalising Economy

Table 4.3: Exports by Factor Intensity Groupings, 1980-2005 (\% or \$ Million)

\begin{tabular}{|c|c|c|c|c|c|c|c|}
\hline \multicolumn{2}{|c|}{ 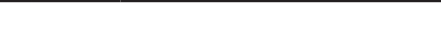 } & 1980 & 1985 & 1990 & 1995 & 2000 & 2005 \\
\hline \multicolumn{2}{|c|}{ Resource Intensive } & 142 & 1,090 & 3,641 & 6,283 & 6,937 & 7,555 \\
\hline \multicolumn{2}{|c|}{$\%$ Share of total manufacturing } & 29 & 55 & 41 & 28 & 20 & 19 \\
\hline \multicolumn{8}{|c|}{ Major Item(s) } \\
\hline 641 & Paper and paperboard & 0 & 21 & 123 & 731 & 1,745 & 2,030 \\
\hline 634 & Veneers, plywood, etc. & 68 & 941 & 2,785 & 3,825 & 2,287 & 1,669 \\
\hline 635 & $\begin{array}{l}\text { Wood manufactures } \\
\text { nes }\end{array}$ & 5 & 11 & 274 & 837 & 939 & 1,001 \\
\hline 625 & $\begin{array}{l}\text { Rubber tyres, tubes, } \\
\text { etc. }\end{array}$ & 0 & 7 & 66 & 182 & 293 & 650 \\
\hline 522 & $\begin{array}{l}\text { Inorganic chemical } \\
\text { elements, oxides, etc }\end{array}$ & 2 & 35 & 27 & 68 & 172 & 388 \\
\hline \multicolumn{2}{|c|}{ Labour Intensive } & 165 & 617 & 4,167 & 10,226 & 13,100 & 13,523 \\
\hline \multicolumn{2}{|c|}{$\%$ Share of total manufacturing } & 34 & 31 & 47 & 45 & 38 & 34 \\
\hline \multicolumn{8}{|c|}{ Major Item(s) } \\
\hline 821 & $\begin{array}{l}\text { Furniture and parts } \\
\text { thereof }\end{array}$ & 3 & 7 & 286 & 864 & 1,528 & 1,862 \\
\hline 651 & Textile yarn & 3 & 13 & 109 & 813 & 1,327 & 1,622 \\
\hline 843 & $\begin{array}{l}\text { Women's outwear } \\
\text { non-knit }\end{array}$ & 24 & 115 & 471 & 886 & 1,324 & 1,361 \\
\hline 851 & Footwear & 1 & 8 & 561 & 1,998 & 1,605 & 1,348 \\
\hline 845 & $\begin{array}{l}\text { Outer garments knit } \\
\text { non-elastic }\end{array}$ & 2 & 26 & 389 & 621 & 896 & 1,129 \\
\hline \multicolumn{2}{|c|}{ Capital Intensive } & 185 & 301 & 1,378 & 6,803 & 12,561 & 14,147 \\
\hline \multicolumn{2}{|c|}{$\%$ Share of total manufacturing } & 38 & 14 & 13 & 27 & 42 & 47 \\
\hline \multicolumn{8}{|c|}{ Major Items(s) } \\
\hline 752 & $\begin{array}{l}\text { Automatic data } \\
\text { processing equip't }\end{array}$ & 0 & 0 & 0 & 170 & 2,018 & 1,850 \\
\hline 763 & $\begin{array}{l}\text { Sound recorders, } \\
\text { phonographs }\end{array}$ & 0 & 0 & 2 & 693 & 823 & 1,275 \\
\hline 764 & $\begin{array}{l}\text { Telecom equip, parts, } \\
\text { accessories }\end{array}$ & 1 & 7 & 60 & 389 & 1,752 & 1,157 \\
\hline 778 & $\begin{array}{l}\text { Electrical machinery } \\
\text { nes }\end{array}$ & 3 & 1 & 65 & 387 & 662 & 1,129 \\
\hline \multirow[t]{3}{*}{772} & $\begin{array}{l}\text { Switchgear etc, parts } \\
\text { nes }\end{array}$ & 1 & 0 & 0 & 106 & 471 & 1,128 \\
\hline & & 491 & 2,007 & 9,186 & 23,312 & 32,598 & 35,225 \\
\hline & & 100 & 100 & 100 & 100 & 100 & 100 \\
\hline
\end{tabular}


These reforms 'worked' in the sense that there was the strong and immediate export response observed above. Indonesia grew quickly out of the early 1980s recession and, although external debt rose sharply in the mid-1980s, debt/GDP ratios remained comfortable, and began declining from the end of the decade. The reforms were also good for equity, as employment expanded significantly in the new export-oriented factories on Java. For the first time in its history, Indonesia became 'East Asian' in the sense of emerging as a major industrial exporter.

A fourth feature is the country's ownership patterns, which are unusual in some respects. There are high levels of ownership concentration, both in the sense of corporate conglomeration and seller concentration. Claessens et al (2000) have documented the former, finding that Indonesia exhibited the highest level of corporate concentration in East Asia in 1996, with the top 10 families owning 57.7 per cent of listed corporate assets. ${ }^{3}$ In terms of plant-level industrial concentration, Bird (1999) found high levels of concentration, typical of those in relatively small, late-industrialising economies. Over the period 1975-93, concentration levels were declining steadily, though in the latter year the simple average 4-firm concentration ratio was still 54 per cent. Concentration ratios were significantly lower once allowance is made for imports.

Indonesia's industrial ownership patterns reflect the interplay of history, policy and industrial organisation factors. In the mid-1960s, no foreign capital was present, and the 'commanding heights' of the economy, such as they were, were in state hands. The state-owned enterprise (SOE) sector continued to be important throughout the Soeharto era. Indeed, there were never any significant privatisations, in any of the country's three modern economic crises, that is, in the mid-1960s, the mid-1980s, and the late 1990s. The oil boom period financed a major expansion in the SOE sector, initially in heavy industry, and later the Habibie high-tech projects. Meanwhile, foreign investment returned to the country from the late 1960s in response to the newly liberal policy regime and generous fiscal incentives. Initially, most of it went into import substituting 'tariff factories'. Then, responding to the reform signals in the first half of the 1980s, efficiency-seeking, export-oriented investments became more important.

As is the case in most countries, domestic firms are the major players in Indonesian industry. They account for more than 50 per cent of manufacturing value added in all 2-digit industries except ISIC 38 (fabricated metals, dominated by electronics) and the relatively minor ISIC 39 (miscellaneous manufacturing). They also employ most of the industrial workforce in aggregate (79 per cent),

3 That is, in terms of the shares of its leading conglomerates in output and capitalisation. Note, however, that the mid-1990s data were dominated by Soeharto-linked conglomerates that have since been largely dismantled, and thus the figure would be lower now. 
including at least one-half in all 2-digit industries. Among domestic firms, SOEs are important in certain 'strategic' industries, such as fertilizer, steel and cement, together with some firms that were inherited from the pre-1966 nationalisations (eg, sugar processing) and never subsequently relinquished. During the recent crisis, the SOE sector in general contracted, especially in the case of the prestige projects, which were heavily dependent on direct government support. Other firms have been accidentally nationalised as part of the 1997-98 financial crisis, but the government has indicated that it intends to divest most of them.

Foreign ownership has risen steadily since the economy was opened up in the late 1960s. The share of these firms in non-oil manufacturing value added rose from about 23 per cent in 1975 to 29 per cent in 1995 (Table 4.4). The share rose higher still in the wake of the crisis, in response to policy liberalisations and the opportunity for foreign firms to buy distressed local assets. Moreover, as we will document below, foreign firms have been better able to endure the crisis. As is evident in the 2-digit ownership data, and consistent with industrial organisation theory, multi-national enterprises (MNE)s are important in ISIC 38, dominated by electronics and the automotive industry. They are also important in basic metals (principally steel and related products), the chemical industries, and a few labour-intensive activities (textiles, garments, footwear and miscellaneous manufactures) where knowledge of export markets is important.

Table 4.4: Share of Foreign Ownership in Manufacturing Value Added (\%)

\begin{tabular}{lrrrrrr}
\hline Sector & 1980 & 1985 & 1990 & 1995 & 2000 & 2004 \\
All sectors & 30 & 22 & 22 & 29 & 39 & 36 \\
31. Food and beverages & 21 & 12 & 8 & 11 & 16 & 22 \\
32. TCF & 22 & 29 & 17 & 24 & 35 & 34 \\
33. Wood products & 12 & 13 & 10 & 12 & 9 & 14 \\
34. Paper products & 13 & 9 & 30 & 32 & 12 & 28 \\
35. Chemicals & 42 & 27 & 34 & 41 & 46 & 33 \\
36. Non-metal products & 55 & 41 & 21 & 25 & 38 & 35 \\
37. Iron and steel & 32 & 19 & 24 & 43 & 39 & 24 \\
38. Machinery, autos etc & 44 & 29 & 46 & 44 & 66 & 63 \\
39. Other & 60 & 41 & 20 & 62 & 48 & 30 \\
\hline
\end{tabular}

\section{After the New Order: deep crisis and adjustment since 1997}

As we have seen, the industrial sector contracted very sharply in 1998, at about the same rate as the economy as a whole. Its recovery since then has been at about the same rate as other sectors. This is largely as would be expected: unless 
there are large, sector-specific events (such as an oil boom), or a very rapid loss in comparative advantage (as has occurred in agriculture in some very high-growth, resource-poor economies), economy-wide factors are the major determinant of sectoral growth rates.

But what is of particular interest, and the focus of this section, is whether (and if so why) the crisis affected industries and firms more or less uniformly. Both theory and intuition would suggest that the effects would be uneven. There were three major events at the time of the crisis: a very sharp contraction in growth rates, from about 7 per cent per annum pre-crisis to -13 per cent in 1998; a collapse in the dollar exchange rate, from about Rp2500 to below Rp10,000 (and bottoming out at Rp17,500); and the near collapse of the formal financial sector. Given that the manufacturing sector comprises a collection of highly heterogeneous enterprises in terms of key attribute-age, size, technology, ownership patterns, sales orientation, debt-structure, location, not to mention entrepreneurial propensities - it would be very surprising if all firms responded to these major events in a similar fashion. For example, a firm that was capitalintensive, highly leveraged to US dollar denominated debt, and selling primarily in the domestic market would be among the most severely affected. This was broadly the case among, for example, steel and auto producers. By contrast, labour-intensive firms with low debt and exporting most of their output would be expected to be largely unaffected by the crisis; in fact to even benefit from it owing to the highly favourable exchange-rate movements from mid-1997. Such an outcome, with a lag, could be observed among some of the country's garment exporters, for example.

More formally, if the impact of the crisis was uneven across firms, what factors what firm and industry attributes - might be expected to have shaped firmlevel responses to the crisis? We hypothesise the following:

Sales orientation of firms: Export-oriented firms are expected to perform better than domestic-oriented ones. This is principally because the former are able to take advantage of the boost to competitiveness from the sharp exchange-rate depreciation. Moreover, and importantly for Indonesia's recovery, unlike eras of generalised recession the global economy continued to be buoyant over this period.

Ownership: Foreign firms should be less affected. They have 'deeper pockets', are less connected to the failing domestic financial sector and, with their global market reach and knowledge, they are able to quickly facilitate sales redirection from domestic to export markets.

Size: The impact on firms of differing size is not clear. Large firms might be expected to be more competitive, owing to economies of scale and stronger 
financial resources. Yet, in the face of extreme shocks to the business environment, small firms are sometimes more flexible and nimble, they are less 'top heavy', and they may be less heavily indebted.

Industry: Firms in labour- and natural-intensive industries should be less affected compared to those in capital-intensive industries. Exchange rate movements will be expected to reinforce Indonesia's comparative advantage in these activities, particularly in the case of the high domestic value-added resourcebased industries. Firms in these industries are also more likely to be exportoriented, and thus they have a 'head start' in shifting to exports. By contrast, firms in capital-intensive industries, in which Indonesia does not typically have a comparative advantage, are more likely to be domestic-market oriented, more likely to receive import protection (which was generally lowered during the crisis), and they are more likely to be heavily indebted.

To address these questions, we draw upon a data set that is unusually rich by developing country standards. This is the annual survey of large and medium firms conducted by Indonesia's Central Board of Statistics (Badan Pusat Statistik, BPS). ${ }^{4}$ This series is designed to survey all large and medium non-oil manufacturing establishments, defined as those employing at least 20 workers. The survey is published as Statistik Industri, but we utilise here the unpublished, establishment-level data tapes. The survey questionnaire covers most operating aspects of these establishments. Crucially for our purposes, establishments are identified by a code, which enables them to be traced over time. We are thus able to construct a very rich panel data series, and to examine the behaviour of firms over this period of growth, crisis and recovery. These data constitute the source of information contained in Figure 1 and the tables that follow.

While the survey is comprehensive, inevitably there are some gaps in the coverage. Two in particular limit our analysis. First, as noted, the unit of observation is the establishment not the enterprise. Thus we cannot detect whether an establishment is a stand-alone operation or is part of a business group. More broadly, given the importance of business conglomerates and the business-finance nexus, especially in the late Soeharto era, firm behaviour at the time of the crisis could presumably have been influenced by membership of a conglomerate, especially one which was 'palace-connected' or linked to an affiliated bank. This is a major limit on any detailed political economy analysis of the impact of the crisis. Second, the survey provides some information on firms' debt and leverage, but the details are incomplete. For example, there are

4 Note that, for expositional convenience, we use the terms 'firm' and 'establishment' interchangeably, but strictly speaking in all cases we are referring to the latter concept. 
no data on the currency in which the debt is denominated, the nature of the financial institution (on- or off-shore, state, private or foreign, etc) and whether the borrowings were hedged.

We measure the impact of the crisis by taking the percentage difference in the level of some performance measures for each firm between the period of crisis and immediate adjustment (that is, 1997-2000) and the pre-crisis period 199596. That is, the two years immediately prior to the crisis are arbitrarily but plausibly taken as our benchmark period. This period could have been shorter or longer, but two years is arguably sufficient to capture conditions prior to the crisis. Note that the data are collected on an annual basis, and therefore it is not possible to capture firm dynamics over shorter periods. For example, the crisis actually commenced in July 1997, and began to impact on real levels of economic activity by the fourth quarter of that year. But the data are not sufficiently disaggregated to detect these developments.

An investigation of firm-level adjustments should ideally employ a variety of performance indicators, including output, employment, and profitability. Trends in these indicators will likely diverge, since they are measuring different phenomena. For example, typically employment does not decline as sharply as output during a recession, as firms tend to 'hoard' labour, owing to the difficulties or reluctance to shed workers. In the following statistics we focus on just one indicator, real value added, which is arguably the most important. The analysis can also be conducted with reference to other variables.

The crisis severely affected firm demographics, as indicated by entry and exit rates (Figure 4.1). Entry rates, which had previously been buoyant, fell sharply from 1997, to less than half the pre-crisis rates, and remained subdued. Exit rates almost doubled at the peak of the crisis. Since output began to recover in 2000 , the inference is that most of the initial post-crisis expansion was explained by firms that survived the crisis.

The outcomes also differed significantly across major industries, as hypothesised above (See Thee 2000 and Fukuchi 2000). Table 4.5 shows the percentage change in real value added (RVA) by industry over the two immediate pre-crisis years, 1995-96. Some industries actually survived the crisis and even expanded significantly. Examples include the labour-intensive sectors of textiles, garments, footwear (ISIC 32) and the small 'other' group (ISIC 39), and the resource-based sectors, wood and paper products (ISIC 33 and 34). By contrast, heavy industries and machine goods (ISIC 37 and 38) contracted. The effect was very severe in the former group, especially with its protected, uneconomic, state-dominated 
steel industry. These conclusions are formally supported by the factor intensity groupings in Table 4.6, especially for firms in labour-intensive industries. These contracted the least, and were expanding again by 1999-2000. ${ }^{5}$

\section{Figure 4.1: Entry and Exit Rates in Indonesian Manufacturing in Terms of Number of Plants (EN1 and EX1) (\%), 1994-2000}

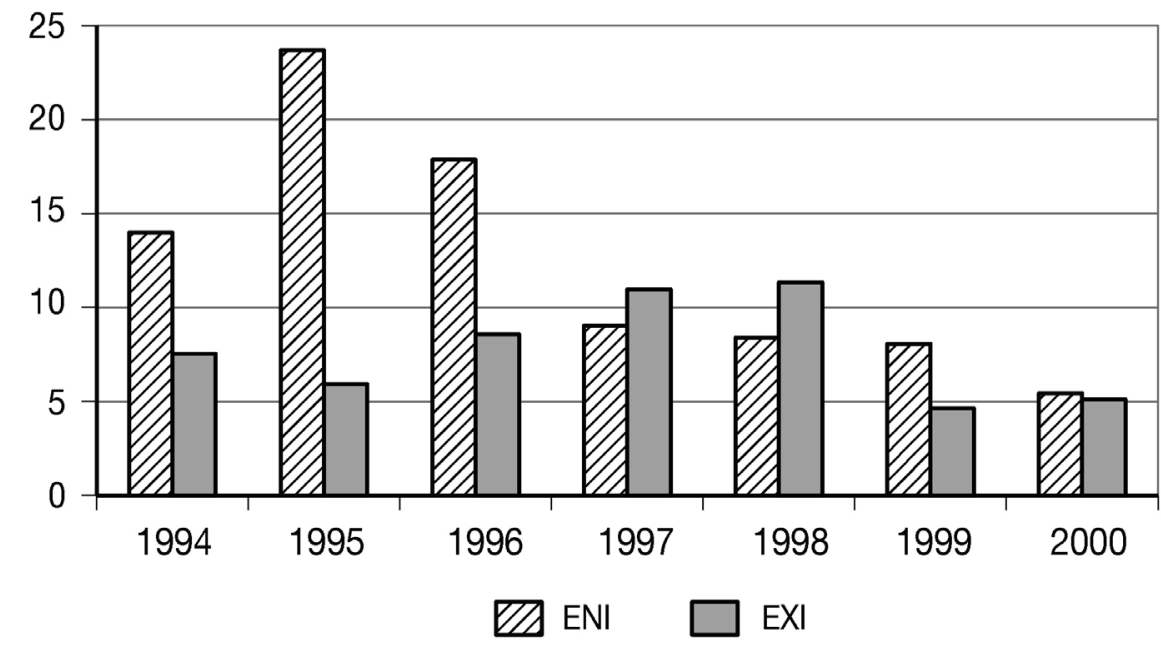

\begin{tabular}{|c|c|c|c|c|c|}
\hline ISIC & Industry & 1997 & 1998 & 1999 & 2000 \\
\hline 31 & Food and tobacco products & 14.3 & 16.8 & 15.4 & 19.5 \\
\hline 32 & Textile, garment and leathers & 8.5 & 30.7 & 18.6 & 24.4 \\
\hline 33 & $\begin{array}{l}\text { Wood products, including } \\
\text { furniture }\end{array}$ & 8.2 & 58.0 & 33.0 & 31.0 \\
\hline 34 & Paper and paper products & 15.7 & 52.0 & 27.5 & 40.0 \\
\hline 35 & Chemical, rubber and plastics & 33.2 & 16.3 & 49.2 & 64.2 \\
\hline 36 & Non-metallic mineral products & 29.3 & 2.6 & -1.3 & 29.1 \\
\hline 37 & Basic metal industries & 22.6 & -74.7 & -69.9 & -63.9 \\
\hline 38 & Machinery and equipment & 4.7 & -3.9 & -3.6 & 56.2 \\
\hline 39 & Other manufacturing & 39.9 & 86.6 & 44.0 & 52.8 \\
\hline
\end{tabular}

Source: Authors' computation.

\footnotetext{
5 Note that, in interpreting the data in Table 4, it is important to bear in mind that there are not many negative numbers because they refer to the difference as compared to 1995-96, which was a high-growth period. There were of course negative annual growth rates during the crisis years, particularly in 1998.
} 
Soeharto's New Order and its Legacy

This is the industry story. What about firm-level effects? Table 4.6 shows these, with firms classified according to the attributes discussed above. Here too we discuss these with reference to changes in real value added compared to the pre-crisis years.

Table 4.6: The Crisis Performance Impact by Plant Characteristics

\begin{tabular}{|c|c|c|c|}
\hline \multirow[t]{2}{*}{ Plant characteristic class } & \multicolumn{3}{|c|}{$\% \Delta$ RVAi,t } \\
\hline & 1998-2000 & 1998 & 1999-2000 \\
\hline \multicolumn{4}{|l|}{ Sales orientation class } \\
\hline Domestic oriented & -19.6 & -22.2 & -12.1 \\
\hline Low export oriented & -19.9 & -22.1 & -13.6 \\
\hline Moderately export oriented & -3.0 & -4.2 & 1.4 \\
\hline Highly export oriented & 8.9 & 11.5 & 5.0 \\
\hline \multicolumn{4}{|l|}{ Ownership class } \\
\hline Foreign & 8.6 & 4.6 & 20.9 \\
\hline Private-domestic & -16.0 & -17.9 & -9.7 \\
\hline Government & -26.6 & -26.3 & -23.7 \\
\hline \multicolumn{4}{|l|}{ Foreign ownership class } \\
\hline Low & -42.5 & -45.4 & -19.1 \\
\hline Moderately low & -6.4 & -14.5 & 18.0 \\
\hline Moderately high & -4.8 & -7.8 & 3.2 \\
\hline High & 31.9 & 29.6 & 38.5 \\
\hline \multicolumn{4}{|l|}{ Size class } \\
\hline Small 1 & -15.4 & -17.4 & -8.5 \\
\hline Small 2 & -21.5 & -23.2 & -15.6 \\
\hline Medium 1 & -17.5 & -19.8 & -11.8 \\
\hline Medium 2 & -11.1 & -13.4 & -5.3 \\
\hline Large & 1.4 & 1.2 & 2.3 \\
\hline \multicolumn{4}{|l|}{ Industry factor intensity class } \\
\hline Resource-intensive & -18.9 & -14.9 & -16.2 \\
\hline Labour-intensive & -5.7 & -9.0 & 1.7 \\
\hline Capital-intensive & -25.0 & -31.7 & -12.8 \\
\hline
\end{tabular}

Source: Authors' computation.

In the case of sales orientation, the firms are classified into four groups, based on pre-crisis patterns: those which sold their output solely in the domestic market and three groups of export orientation. As predicted, sales orientation matters, 
significantly. For example, domestic-oriented firms contracted quite sharply, by around 20 percent, both in 1998 and through to 2000. By contrast, the highly export-oriented firms (defined as more than 50 per cent of output exported) actually grew quite strongly, by 9 per cent through to 2000. The moderately export-oriented firms (10-50 per cent of output exported) initially contracted somewhat but were growing again by 1999-2000. The low export-oriented firms (0-10 per cent of output exported) performed similarly to those selling to the domestic market. This suggests the possibility of some sort of 'threshold' effect. The story is of course more complicated than this: there are lags, differences across industries, and outcomes depend on conditions in competitor countries (several of which also experienced sharp exchange-rate depreciations). But, undeniably, the key message is that export orientation was a key to recovery.

In the case of ownership, the firms are classified into three groups: domestic (private), state and foreign, again defined from the pre-crisis period. Here too there are significant differences, and the results conform to a priori hypotheses. The deep-pocketed and well connected foreign-owned firms (technically, defined as those with any foreign ownership) continued to expand, and at a faster pace from 1999. By contrast, both the domestic groups contracted, the SOEs particularly so. The performance of the SOEs deserves special comment. These were invariably inefficient enterprises, for a variety of reasons related to their multiple objectives, social missions, top-heavy management and poor incentives systems. In good times, the government was able to effectively bankroll them either directly or via the financial sector. When these props were removed during the crisis, the SOEs were unable to adjust. Their location in capital-intensive industries, which was in most cases deliberately part of their mandate, further compounded the problems.

Since the foreign-owned group includes all firms with foreign firms, it is useful to examine whether the levels of foreign ownership matter. One might expect a positive relationship between these levels and firm performance, on the grounds that the parent company might be more committed to its affiliateand have more control over it - the higher its stake. The data in Table 5 reveal this to be very much the case: firms with high foreign ownership ( 80 per cent plus in 1995-96) grew strongly throughout the period, whereas the low foreign ownership (less than 20 per cent) group contracted, in fact even more than the two domestic groups. The two intermediate groups of firms initially contracted but, unlike the domestic groups, they were expanding again in 1999-2000. Interestingly, and contrary to expectations, majority ownership does not appear to have been the critical consideration. That is, the benchmark defining whether foreign ownership matters appears to be more than just majority ownership, but in fact a very high foreign share. 
Firms were also classified into five size groups, based on the size of their workforce: 20-49, 50-99, 100-199, 200-499, and 500+ workers. We argued above that there was no clear theoretical guidance for outcomes based on size. A popular literature in Indonesia at the time of the crisis asserted that small firms were more likely to have survived, but there is significant empirical evidence to the contrary. The results in Table 5 suggest that size is not a key variable, other than for the very large firms, which continued to grow, albeit slowly, after 1997. Among the other groups, the differences are not large, with the smallest and largest groups contracting somewhat less. As we will see shortly, the differing performance across size groups also reflects the effects of other factors, notably ownership and sales orientation.

The analysis thus far has been a single-variable story. Obviously though, as argued above, a variety of firm characteristics combine to produce the final outcome. Typically, these variables go hand in hand: larger firms are more likely to be foreign-owned and export-oriented, for example. Econometric analysis is required to investigate the impact of these factors. This is beyond the scope of our chapter, but drawing on Narjoko (2006), the following findings emerge. The first is the importance of export orientation, the effects of which are positive and statistically significant. As expected, the effect weakens over time, reflecting the fact that the initial sharp nominal depreciation was subsequently eroded by high inflation. Similarly, the positive relationship between foreign ownership and performance is confirmed. The results also show that the share of the foreign partner matters, and that the minimum foreign share required to ensure no firm contraction is quite high, about 40 per cent.

In addition to the impact of these attributes separately, we also examined the interactive effect of sales orientation and foreign ownership, on the presumption that the two are likely to be highly interrelated. That is, both the performance and survival of export-oriented firms may well depend on foreign ownership, as the latter may well facilitate a faster switching effect owing to these firms' knowledge of international markets and their stronger financial position. The results support this prediction. That is the effect of export orientation in lowering output contraction was higher in plants with high foreign ownership shares.

In the case of size, the regression results differ from the descriptive analysis, in that they suggest that larger firms contracted more than smaller ones. However, the results are generally weakly significant. 


\section{Conclusions}

To return to our main questions, these contrasting episodes, of rapid growth over three decades followed by a very sharp contraction in 1997-98, draw attention to the highly episodal nature of Indonesian economic development. They have important implications more generally for any assessment of the Soeharto regime and for managing the industrialisation process. In particular, they highlight both the opportunities presented by opening up to the global economy but also the challenges, and by implication the importance of introducing a range of complementary policy and institutional reforms to manage this process. In aggregate, of course, Indonesia is a much richer country now compared to the mid-1960s, even after the crisis and slower growth of the past decade. But a clear lesson is that, while the country has benefitted from its more open economic policies, deep crises are economically very disruptive and socially painful. Clearly, policies need to be set in place to avoid them as far as possible. Many of these broader lessons go well beyond this chapter, and most are not industryspecific, but it will be useful by way of summary to briefly draw attention to some of the key issues.

The main positive message learnt from the New Order experience is that an open trade and investment regime and efficient supply-side investments were beneficial for Indonesia. This can be seen from Indonesia's three decades of rapid growth and the rapid improvement in living standards. A number of lessons stand out. One is that the country has grown rapidly when it has opened up its trade and investment policies. This was illustrated in the two major liberalisation episodes, in 1966-68 and 1982-86. In both cases, the economy responded swiftly and growth accelerated to 7-8 per cent. Of course, this was a 'liberalisation plus' story, in which a range of additional pre-requisites was also present: sound macroeconomic management, regime credibility, international support, and an expanding, largely open global economy.

Other elements of the commercial and social policy regime have underpinned these reforms. There were massive investments in infrastructure during the Soeharto era, particularly in the road network. By the mid-1990s, the country's physical infrastructure was at least as good as that in comparable countries (eg, China) and in most cases superior. The sharp decline in infrastructure post-crisis is now looming as a key constraint on growth. There was also a large expansion in education participation rates from the late 1960s, with almost universal primary school enrolments by 1980. In this respect, Indonesia was certainly 'East Asian' rather than 'South Asian', in that mass schooling enabled greater social mobility and participation. It also served to strengthen the country's capacity to absorb, and benefit from, greater openness to foreign capital and trade. But arguably Indonesia could have done better in tapping into global opportunities. Although 
education was broad-based, the technical and higher education sectors remain relatively under-developed. Moreover, the government's industrial support and extension programs have generally been weak, poorly targetted, with limited and unpredictable funding, and vulnerable to capture by vested interests. In this respect, Indonesia differs from the earlier experience of Korea and Taiwan, and more recently China. Its industrial upgrading process is therefore likely to proceed more slowly (Chu and Hill eds 2006).

While three decades of strong growth amply illustrate the benefits of openness, the deep crisis of 1997-98 is testimony to the pitfalls. The origins of the crisis are still being debated: between fundamental causes and triggers, and between domestic and international factors. ${ }^{6}$ But there can be no doubt that the sudden change in risk assessments which prompted the capital flight, initially from Thailand and subsequently some of its neighbours, underlines the importance of managing integration into the global economy.

Three key lessons have emerged from the crisis. One is that global commercial integration in turn demands international-quality institutions and regulatory capacity where it really matters. Especially important are the key areas of financial supervision, central bank management, the finance ministry, and commercial law enforcement. Weaker capabilities in these areas are likely to result in slower growth and greater vulnerability to crises. Second, exchangerate management is critical, since it is the major price variable through which a crisis is initially transmitted. Like most of its neighbours, Indonesia ran a fixed but adjustable regime prior to the crisis. Economic agents responded to the façade of certainty, and borrowed heavily in foreign currencies. One lesson from the crisis episode is that this strategy of attempting to fix (or heavily manage) the nominal rate in the face of large and potentially volatile short-term capital flows is highly risky. Hence the advocacy of the so-called 'corner solutions', either in the form of floating rates or hard pegs. In the wake of the crisis, Bank Indonesia has adopted a floating rate regime, albeit heavily managed, and the business community appears to have adjusted surprisingly quickly to it.

Third, there continue to be calls to manage capital mobility, especially the shortterm, volatile flows. While intuitively attractive, there are obvious risks in such a strategy. It disconnects the country from global capital markets, it requires a high-quality, incorruptible central bank, and it may in any case be impracticable where international boundaries are highly porous. However, there may be a case for light-handed measures which slow short-term capital mobility, but which leave foreign direct investment (FDI) flows unaffected. Some of these measures

6 See Hill, 1999 for an analysis of the crisis and its immediate aftermath, and Temple, 2003 for an interpretation of Indonesia's long-term economic growth up to and through the crisis period. 
could include monitoring short-term flows, limiting the ability of foreigners to borrow in the domestic currency, or imposing a surcharge on capital that exits prior to a defined period.

To connect these lessons back to our analysis of Indonesian industrialisation, these cautionary tales on the impact of globalisation in no way weaken the case for open trade and FDI policies. When properly managed, they have contributed to rapid growth. Moreover, as we have shown, the firms which were the best connected to the global economy, through trade, investment and particularly both, led the country's economic recovery.

For a volume in honour of Professor Harold Crouch, the missing element in the above story is of course the political economy of industrial policy. This has always been one of the most contested and contentious areas of economic policy making in Indonesia, reflecting the struggle between the technocrats, 'nationalists' and a variety of rent seekers. During the Soeharto era, the president effectively adjudicated on policy, guided by the dictum attributed to one of the country's most influential economists, the late Professor Moh Sadli, that 'bad times make for good policies and good times frequently the reverse'. Thus during periods of looming or actual crisis, in the mid-1960s and mid-1980s, the technocrats were allowed to be in the ascendancy, and they delivered major economic reforms that led to recovery and faster growth. During periods of buoyant economic growth, in the 1970s and the first half of the 1990s, they were less influential. In the 1970s, state-led industrialisation was again emphasised, with funding from the oil boom. In the 1990s, the technocrats were again increasingly marginalised, by both the high-tech projects of Dr Habibie and the Soeharto family conglomerates.

A new political economy dynamic has emerged in the post-Soeharto era. Once again, the technocrats held sway at the peak of the crisis, and their power began to wane as recovery got underway. But in this democratic era, there are new, less predictable policy actors. The technocrats are no longer the united group they were under Soeharto, and their modus operandi is different. The executive and bureaucracy are weaker, while the legislature, the regions, labour and civil society have more power. Political parties require funding. By all accounts, corruption is just as serious as it was under Soeharto, but it is now much less predictable. Liberalism remains politically unpalatable. It is therefore likely that the policy pendulum will continue to swing back and forth, as it has periodically since the 1960s, with consequences for Indonesia's long-term development dynamics.

What are the implications for any assessment of Soeharto and his legacy? A decade after the crisis, Indonesian industrialisation appears to have embarked on a different trajectory, one of slower growth, lower investment, weaker 
employment generation (see Chapter 10 by Chris Manning), and indifferent export performance (Athukorala 2006). Initially, the crisis was the main explanation for these trends, but it is clear now that they are primarily the result of the new policy regime, combined with much more severe international competition. That is, first, investors are still holding back, particularly for projects with long-time horizons, owing to uncertainties in the commercial climate. ${ }^{7}$ Second, as noted the country's infrastructure investment lags its neighbours, and is becoming a serious constraint on growth. Third, it is now missing out on East Asian style labour-intensive growth, to the detriment of job-seekers and efforts to achieve rapid poverty reductions. Fourth, Indonesia is not a major participant in the rapidly expanding global production networks that are increasingly centred in East Asia. This in turn is primarily the result of the country's continuing ambivalence towards foreign investment, and its less efficient logistics for these highly trade-oriented operations.

It would of course be simplistic to assert that these problems have arisen only in the post-Soeharto era. All have been present to some degree since Indonesian Independence. The high point of policy reforms in the country was the 1980s, and all administrations since then have found it difficult to maintain the pace of reform. When major economic and political crises occur, economic policy making becomes that much more difficult. For most of the Soeharto era, Indonesia outperformed its fellow developing Asian giants, China and India. The challenge now is to try to keep up with them.

7 For example, according to the World Bank's Doing Business 2008 report, Indonesia ranks 123 out of 178 economies, below its more developed Southeast Asian neighbours Singapore (1), Thailand (15), Malaysia (24), as well as Vietnam (91). 